\title{
Understanding Sport Participation Motivation and Barriers in Adolescent 11-17: An Introduction of Rowing Activity in Schools 了解青少年參與賽艇活動的意向 : 在學校推廣賽艇活動
}

\author{
Robert Siu Kuen NG \\ Physical Education section, \\ The Hong Kong Polytechnic University, HONG KONG
}

\section{吳兆權}

香港理工大學體育組

\begin{abstract}
The purpose of this study is to identify the drivers and barriers perceived by the adolescents for their desire to participate in rowing activity. 1,333 secondary school students, including 762 boys, 565 girls, and 6 students whose gender are not specified, aged from 11 to 17 participated in the survey after taking a rowing promotion programme and an 1min maximal rowing ergometer test. The findings highlight that the male adolescents have stronger desire in taking rowing activity, besides, the desire seems to decline with the age in both gender groups. The female adolescents emphasize the enjoyment they gained in rowing activity, while the male adolescents concern final achievements more. Lack of interest is the most stated reason for their no intention to start rowing activity. Recommendations are suggested to meet the different motivational demands by adjusting the contents of the promotion programme or providing various programmes.
\end{abstract}

摘 要

本研究探討青少年在學校推廣賽艇活動之後, 影響他們參與賽艇活動的意向及考慮因素。共1,333名中學生(762男, 565女, 6 位沒有填上性別)完成校內賽艇推廣活動之後進行問卷調查。研究發現：1) 男女生參與的意向隨著年紀增長而下降, 男生參加賽 艇活動的意向比女生大。2) 男女生參與的原因分別是著重參與所得到的樂趣和運動成績。而他們提出不想參加賽艇活動的原因是 不感興趣。提議：在賽艇推廣活動中可調節內容和提供多元化的活動，從而迎合他們的不同需要。

關鍵詞： 參與運動、動機、障礙、青少年、賽艇、學校

\section{Introduction}

Regular physical activity (PA) is associated with immediate and long-term benefits including lower rates of obesity, improved cardiovascular and muscular fitness, higher bone mineral density, improved psychosocial health, and academic achievement among children and adolescents (Centers for Disease Control and Prevention, 2008; Etnier et al., 1997; Shephard, 1997; Strauss, Rodzilsky, Burack
\& Colin, 2001; Symons, Cinelli, James \& Groff, 1997). Besides, establishing patterns of PA during childhood and adolescence is important to develop positive behaviours that can be deployed throughout the life course.

Although PA brings such considerable benefits in physiological, psychological, and academic fields, declines in PA levels among children and adolescents was still unfortunately observed (Biddle, Gorely \& Stensel, 2004; 
van Mechelen, Twisk, Post, Snel \& Kemper, 2000). Some researchers suggested to invoke their participation by offering various of PA programmes for adolescents in America (Dwyer et al., 2006), United Kingdom (Mulvihill, Rivers \& Aggleton, 2000) and Australia (Fawcett, Garton \& Dandy, 2009).

According to the process model of participation motivation in sport and exercise suggested by Busby (1997), intention is the immediate determinant of a decision to act. A lot of studies showed that intention is a predictive index of exercise behaviour (Dzewaltowski, Noble \& Shaw, 1990; Riddle, 1980). Several researchers investigated the differences in youth motives across sports, age, and gender and suggested that children and adolescents are subject to the environmental influences in their motivation to participate in certain physical activities (Brustad, 1988; Duda, 1985; Gould, Feltz \& Weiss, 1985; White \& Duda, 1994).

The participation motives related to rowing sport is scared. Rowing in Hong Kong is not popular among adolescents compared with other traditional PA (Hong Kong Sports Development Board, 2000). The benefits of rowing have been demonstrated. It is an aerobic exercise with low impact, and the intensity is completely controlled by participants, making it suitable for people of all ages and all walks of life. The smooth, rhythmic motion of rowing involved many muscle groups. It can be both recreational, focusing on learning the techniques required, and competitive where overall fitness plays a large role. The participants can be trained by rowing ergometer, water sculling (two oars) or rowing (one oar) with a variety of boat types.

Allender, Cowburn and Foster (2006) underwent a critical review of qualitative research from 1990 to 2004 to examine the barriers and motivation to participation in sport and PA in the United Kingdom, they concluded that there was no study reporting the barriers to participate in sport and PA facing among young children. Therefore, the purpose of this study is to investigate the intention of the adolescents in Hong Kong in participating rowing activity and the factors that might influence their decision. Finally, a motivation model of PA participation in rowing will be constructed.

\section{Methods}

\section{Instrumentation}

The questionnaire was adapted and modified from Sports Council for Northern Ireland (SCNI) survey (Kremer, Trew \& Ogle, 1997). The two-page-questionnaire in both English and Chinese consists of three sections: (a) personal information including age, gender, level of involvement in $\mathrm{PA}$, and score of 1-min maximal rowing ergometer test, (b) the evaluation of coach and Youth Rowing Development Programme (YRDP) and (c) their behavioural outcome of persistences which were assessed by asking their intention of participating rowing activity and by ranking the top five reasons for making their choice in an index from 1 to 5 in which the value of "1" is the strongest.

The questionnaire was conducted in an informal discussion and was evaluated by three rowing coaches. It was then pre-tested on twenty (12 male and 8 female) students who were training in rowing beginner course. The purpose of the pilot study was to collect and analyse qualitative data in terms of clarity, ambiguity, order, appropriateness of information sought, suitability of response format, and overall coverage of the questionnaire. Only minor wording and design was changed to improve the content of the draft questionnaire, and made it easier to complete. A test retest reliability was carried out with forty (20 male and 20 female) Form Four students from one of the secondary schools in East New Territories (N.T.) of Hong Kong. They completed two questionnaires twice with one hour apart. The Cronbach's coefficient alpha of between 0.845 and 1 was revealed for the instrument.

\section{Procedures}

Three aided secondary schools in three districts in East NT of Hong Kong were selected to participate in the YRDP organized by the Hong Kong, China Rowing Association. The contents of the activity include an introduction of rowing, height and weight measurement, demonstration of indoor rowing, and 1-min maximal rowing ergometer test. The data were collected during physical education class from September to October 2008. All students studying from Secondary Form 1 to Form 4 completed a physical activity readiness questionnaire and an informed written consent form, which was filled out by both the parents and the students before 
participating in the survey and 1-min maximal rowing ergometer test. A trained researcher who is a qualified rowing coach administered the questionnaire and the test. No incentive was provided for participation. Students responded to the questionnaire anonymously and were assured about the confidentiality of their answers.

\section{Data Analysis}

Their intentions to participate in rowing activity with stated reasons are described in frequencies and percentages. The top five stated reasons by each adolescent are recoded so as a comparison among the stated reasons could be carried out. The reason ranked number $1,2,3,4$ and 5 received a score of $5,4,3$, 2 and 1 respectively. Larger sum of the scores indicate much more importance of the reason for their choices. In addition, Chi-square analysis is used to determine if significant relationship existed between their intention and i) age difference, ii) gender and iii) the score of 1- min maximal rowing ergometer test. A series of t-test were performed to examine whether the effectiveness of YRDP affected their intentions to join the rowing activity. The alpha level was set at $\mathrm{p}<.001$ to determine the significance of the statistical relationship. All analyses were undertaken using the SPSS for Windows software package (Version 17).

\section{Results}

A total of 1,333 out of 1,400 questionnaires were received, representing $95.2 \%$ response rate. The participants were 1,333 secondary school students (762 boys, 565 girls; 6 with gender not specified). All students are Chinese. They ranged in age from 11 to 17 years old (mean = 13.51; $\mathrm{SD}=1.38$ ).

About one-third of the male adolescents (29.7\%) and one-seventh $(14.0 \%)$ of the female adolescents reported that they had regular PA participation. Among the exercisers, more than half of them (54.9\%) were school representatives (see Table 1).

Table 1. Participation in PA of the Adolescents.

\begin{tabular}{|l|c|c|c|}
\hline & All $(\mathrm{n}=226)$ & Female $(\mathrm{n}=79)$ & Male $(\mathrm{n}=147)$ \\
\hline Recreation & $29.6 \%(\mathrm{n}=67)$ & $34.2 \%(\mathrm{n}=27)$ & $27.2 \%(\mathrm{n}=40)$ \\
School Representative & $54.9 \%(\mathrm{n}=124)$ & $51.9 \%(\mathrm{n}=41)$ & $56.5 \%(\mathrm{n}=83)$ \\
Club Representative & $6.6 \%(\mathrm{n}=15)$ & $5.1 \%(\mathrm{n}=4)$ & $7.5 \%(\mathrm{n}=11)$ \\
Regional Squad & $6.6 \%(\mathrm{n}=15)$ & $8.9 \%(\mathrm{n}=7)$ & $5.4 \%(\mathrm{n}=8)$ \\
Junior Squad & $1.3 \%(\mathrm{n}=3)$ & $0 \%$ & $2.0 \%(\mathrm{n}=3)$ \\
National Squad & $0.9 \%(\mathrm{n}=2)$ & $0 \%$ & $1.4 \%(\mathrm{n}=2)$ \\
\hline
\end{tabular}

\section{Intention to Participate in Rowing Activity}

Table 2 shows more male adolescents (31.0\%) than female adolescents (25.1\%) expressed the interest in starting rowing activity. More female adolescents (75.2\%) than male adolescents (69.7\%) who are not current participating in PA had intentions to start rowing activity. Figure 1 displays about one-fifth (20.2\%) of male adolescents expect to be trained to a more advance level than the female counterparts $(8.0 \%)$. The chi-square results showed a significant decline in desiring to start rowing activity while age increased. More adolescents indicated their intentions at age of 12 and their intentions was the lowest at age of 15 in female adolescents, $X^{2}(6, n=$ $515)=46.08, \mathrm{p}<.001$ and male adolescents, $X^{2}(6, n$ $=654)=32.70, \mathrm{p}<.001$. 
Table 2. Intention to Participate in Rowing Activity and PA Participation Background.

\begin{tabular}{|c|c|c|c|c|c|c|}
\hline Intention & \multicolumn{3}{|c|}{ YES } & \multicolumn{3}{|c|}{ NO } \\
\hline Variables & All & Female & Male & All & Female & Male \\
\hline Respondents & $28.4 \%(\mathrm{n}=335)$ & $25.1 \%(\mathrm{n}=130)$ & $31.0 \%(n=205)$ & $71.6 \%(\mathrm{n}=845)$ & $74.9 \%(\mathrm{n}=388)$ & $69.0 \%(n=457)$ \\
\hline Age (Years) & $13.1 \pm 1.4$ & $12.8 \pm 1.4$ & $13.3 \pm 1.4$ & $13.6 \pm 1.4$ & $13.5 \pm 1.4$ & $13.7 \pm 1.3$ \\
\hline PA Participation & & & & & & \\
\hline Yes & $28.2 \%(\mathrm{n}=87)$ & $24.8 \%(n=30)$ & $30.3 \%(\mathrm{n}=7)$ & $14.1 \%(n=119)$ & $11.1 \%(n=43)$ & $16.6 \%(\mathrm{n}=76)$ \\
\hline No & $71.8 \%(n=222)$ & $75.2 \%(n=91)$ & $69.7 \%(\mathrm{n}=131)$ & $77.9 \%(n=658)$ & $78.6 \%(n=305)$ & $77.2 \%(n=131)$ \\
\hline
\end{tabular}

Figure 1. Intention to Participate in Rowing Activity with Expected Status (n = 281).

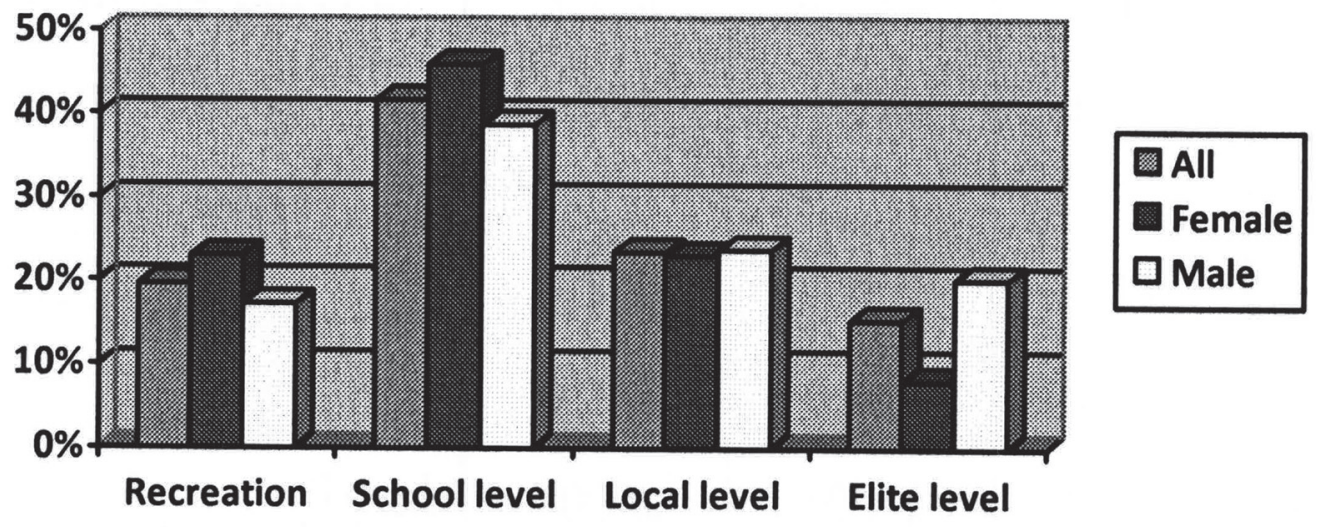

\section{Expected Status}

The Most Important Reasons for their Intention of Participating in Rowing Activity by Gender

Table 3 shows the percentage and the sum of scores obtained from recoding, the female and male adolescents indicate their most important reason out of the 15 choices for their intention of participating in rowing activity are "to have fun" and "like the challenge" respectively.

Table 3. The Frequency of Stated Reasons in Percentage Scores and Sum of Percentage Scores for their Intention to Participate in a Rowing Activity.

\begin{tabular}{|l|c|c|c|c|c|c|}
\hline & \multicolumn{3}{|c|}{ Percentage scores } & \multicolumn{3}{c|}{ Sum of percentage scores (total score) } \\
\hline Reasons for participation & $\begin{array}{c}\text { All } \\
\mathrm{n}=335\end{array}$ & $\begin{array}{c}\text { Female } \\
\mathrm{n}=130\end{array}$ & $\begin{array}{c}\text { Male } \\
\mathrm{n}=205\end{array}$ & $\begin{array}{c}\text { All } \\
\mathrm{n}=335\end{array}$ & $\begin{array}{c}\text { Female } \\
\mathrm{n}=130\end{array}$ & $\begin{array}{c}\text { Male } \\
\mathrm{n}=205\end{array}$ \\
\hline To have fun & $16.5 \%$ & $21.7 \%$ & $13.8 \%$ & $15.2 \%(827)$ & $18.3 \%(378)$ & $13.4 \%(449)$ \\
Like the challenge & $15.6 \%$ & $15.7 \%$ & $15.6 \%$ & $15.7 \%(849)$ & $16.6 \%(342)$ & $15.1 \%(507)$ \\
Learn new sport & $11.9 \%$ & $13.0 \%$ & $11.3 \%$ & $12.6 \%(684)$ & $14.0 \%(288)$ & $11.8 \%(396)$ \\
To be physically fit & $11.8 \%$ & $11.3 \%$ & $12.0 \%$ & $12.2 \%(663)$ & $11.4 \%(235)$ & $12.7 \%(428)$ \\
Like the instructor & $7.9 \%$ & $8.7 \%$ & $7.5 \%$ & $7.1 \%(383)$ & $7.0 \%(145)$ & $7.1 \%(238)$ \\
Like the equipment & $7.2 \%$ & $5.7 \%$ & $7.9 \%$ & $5.3 \%(290)$ & $4.4 \%(91)$ & $5.9 \%(199)$ \\
To compete & $6.1 \%$ & $7.0 \%$ & $5.7 \%$ & $8.0 \%(433)$ & $9.2 \%(189)$ & $7.3 \%(244)$ \\
To gain status & $5.7 \%$ & $4.4 \%$ & $6.3 \%$ & $5.6 \%(306)$ & $4.4 \%(90)$ & $6.4 \%(216)$ \\
Do something good at & $4.3 \%$ & $2.6 \%$ & $5.2 \%$ & $5.5 \%(297)$ & $4.2 \%(86)$ & $6.3 \%(211)$ \\
Support from my friends & $3.4 \%$ & $3.9 \%$ & $3.2 \%$ & $3.4 \%(185)$ & $3.4 \%(70)$ & $3.4 \%(115)$ \\
Be with friend(s) & $3.3 \%$ & $1.7 \%$ & $4.1 \%$ & $2.9 \%(155)$ & $2.0 \%(42)$ & $3.3 \%(113)$ \\
Support from my parents & $3.1 \%$ & $2.2 \%$ & $3.6 \%$ & $2.8 \%(152)$ & $2.0 \%(42)$ & $3.2 \%(110)$ \\
Support from school & $1.5 \%$ & $1.7 \%$ & $1.4 \%$ & $2.1 \%(114)$ & $2.4 \%(49)$ & $1.9 \%(65)$ \\
My family member(s) is/are & $1.5 \%$ & & & & & \\
participating & & & $2.3 \%$ & $1.2 \%(68)$ & $0.4 \%(8)$ & $1.8 \%(60)$ \\
Others & $0.2 \%$ & $0.4 \%$ & $0.1 \%$ & $0.4 \%(19)$ & $0.3 \%(7)$ & $0.4 \%(12)$ \\
& $100 \%$ & $100 \%$ & $100 \%$ & $100 \%(5425)$ & $100 \%(2062)$ & $100 \%(3363)$ \\
\hline
\end{tabular}




\section{Reasons for Not Interest to Participate in Rowing Activity by Gender}

In Table 4, the most important reasons the female adolescents stated out of the 17 choices for not interest to participate in rowing activity in descending order were: 1) lack of interest; 2) poor swimming skill; 3) academic problems; 4) not fit enough; 5) lack of confidence, while male adolescents listed 1) lack of interest; 2) poor swimming skill; 3) not fit enough; 4) academic problems; 5) time constraint as their top five reasons. After recoding, the total score showed that "lack of interest" is the top reason indicated by the male and female adolescents.

Table 4. The Most Important Reasons in Percentage Scores and Sum of Percentage Scores for Not Interest to Participate in a Rowing Activity.

\begin{tabular}{|c|c|c|c|c|c|c|}
\hline & \multicolumn{3}{|c|}{ Percentage scores } & \multicolumn{3}{|c|}{ Sum of percentage scores (total score) } \\
\hline Reasons for not participation & $\begin{array}{c}\text { All } \\
(\mathrm{n}=845)\end{array}$ & $\begin{array}{c}\text { Female } \\
(\mathrm{n}=388)\end{array}$ & $\begin{array}{c}\text { Male } \\
(\mathrm{n}=457)\end{array}$ & $\begin{array}{c}\text { All } \\
(\mathrm{n}=845)\end{array}$ & $\begin{array}{c}\text { Female } \\
(\mathrm{n}=388)\end{array}$ & $\begin{array}{c}\text { Male } \\
(\mathrm{n}=457)\end{array}$ \\
\hline Lack of interest & $17.9 \%$ & $18.8 \%$ & $17.5 \%$ & $14.7 \%(1753)$ & $14.5 \%(814)$ & $14.8 \%(939)$ \\
\hline Poor swimming skill & $11.7 \%$ & $12.3 \%$ & $11.3 \%$ & $11.4 \%(1355)$ & $11.0 \%(620)$ & $11.6 \%(735)$ \\
\hline Not fit enough & $9.9 \%$ & $9.3 \%$ & $10.5 \%$ & $10.7 \%(1280)$ & $11.3 \%(632)$ & $10.2 \%(648)$ \\
\hline Academic problems & $9.6 \%$ & $10.1 \%$ & $9.3 \%$ & $9.8 \%(1174)$ & $10.3 \%(577)$ & $9.4 \%(597)$ \\
\hline Time constraint & $7.9 \%$ & $6.8 \%$ & $8.9 \%$ & $9.7 \%(1161)$ & $9.6 \%(537)$ & $9.9 \%(624)$ \\
\hline Lack of confidence & $7.4 \%$ & $7.8 \%$ & $7.2 \%$ & $6.8 \%(815)$ & $6.9 \%(385)$ & $6.8 \%(430)$ \\
\hline Unlike to sun exposure & $5.8 \%$ & $7.1 \%$ & $4.9 \%$ & $6.7 \%(805)$ & $7.0 \%(391)$ & $6.5 \%(414)$ \\
\hline Don't like outdoor event & $5.7 \%$ & $6.8 \%$ & $4.9 \%$ & $6.4 \%(765)$ & $7.8 \%(437)$ & $5.2 \%(328)$ \\
\hline Other commitments & $5.6 \%$ & $4.6 \%$ & $6.5 \%$ & $5.4 \%(640)$ & $5.6 \%(315)$ & $5.1 \%(325)$ \\
\hline No company & $4.9 \%$ & $5.1 \%$ & $4.8 \%$ & $5.4 \%(639)$ & $5.3 \%(296)$ & $5.4 \%(343)$ \\
\hline Long travelling & $4.1 \%$ & $4.2 \%$ & $4.0 \%$ & $3.7 \%(444)$ & $2.9 \%(164)$ & $4.4 \%(280)$ \\
\hline Health problems & $2.5 \%$ & $2.9 \%$ & $2.3 \%$ & $2.6 \%(311)$ & $2.2 \%(124)$ & $3.0 \%(187)$ \\
\hline No support from family & $2.5 \%$ & $2.4 \%$ & $2.7 \%$ & $2.4 \%(284)$ & $2.0 \%(113)$ & $2.7 \%(171)$ \\
\hline Financial constraint & $2.2 \%$ & $1.2 \%$ & $3.1 \%$ & $1.9 \%(228)$ & $1.8 \%(103)$ & $2.0 \%(125)$ \\
\hline Others & $1.0 \%$ & $0.1 \%$ & $0.1 \%$ & $1.0 \%(120)$ & $0.9 \%(52)$ & $1.1 \%(68)$ \\
\hline No support from school & $0.8 \%$ & $0.4 \%$ & $1.2 \%$ & $0.8 \%(93)$ & $0.5 \%(28)$ & $1.0 \%(65)$ \\
\hline Coaches are unfriendly & $0.5 \%$ & $0.1 \%$ & $0.8 \%$ & $0.6 \%(71)$ & $0.4 \%(23)$ & $0.8 \%(48)$ \\
\hline Total & $100 \%$ & $100 \%$ & $100 \%$ & $100 \%(11938)$ & $100 \%(5611)$ & $100 \%(6327)$ \\
\hline
\end{tabular}

\section{Comparison between Gender Differences}

A chi-square was carried out to investigate the intention of participating rowing activity with respect to gender. The results showed a significant difference between the gender related to their intention of participating rowing activity, $\mathrm{X}^{2}(7, \mathrm{n}=1180)=29.25, \mathrm{p}<.001$. Male adolescents showed stronger intention to participate in rowing than their female counterparts.

\section{Comparison between their Intention and Scores of 1-min Maximal Rowing Ergometer Test}

A t-test was carried out to examine the influence of score of 1-min maximal rowing ergometer test in relation to their intention of participating rowing activity. The results showed that the adolescents with higher score in 1-min maximal rowing ergometer test had significantly stronger intention of participating rowing activity $(\mathrm{t}=2.674$, $\mathrm{df}=994, \mathrm{p}=0.008)$.
Chi-square analysis indicates there is significant difference in respect to the score of 1-min maximal rowing ergometer test in intention versus no intention among female adolescents, $\mathrm{X} 2(7, \mathrm{n}=518)=631.94, \mathrm{p}$ $<.001$, and male adolescents, X2 $(7, \mathrm{n}=662)=199.29$, $\mathrm{p}<.001$.

\section{Relationship of the Effectiveness of YRDP and their Intention}

A series of t-tests were performed to examine whether their level of agreements related to YRDP influencing their intention. As indicated in table 5, the female adolescents statistically have stronger intention in participating rowing activity with higher satisfaction level of the activity in "overall satisfactory level of the activity." ( $\mathrm{t}=7.219$, $\mathrm{df}=485, \mathrm{p}<.001)$ and higher level of agreements in "the activity was interesting." $(t=6.703$, $\mathrm{df}=506, \mathrm{p}<.001)$, "the activity was challenging." $(\mathrm{t}=4.947, \mathrm{df}=505, \mathrm{p}<.001)$, "my knowledge in rowing was enhanced." $(\mathrm{t}=4.937, \mathrm{df}=506, \mathrm{p}<.001)$, 
"my interest in rowing was enhanced." $(\mathrm{t}=8.275$, df $=504, \mathrm{p}<.001)$. The results in table 5 showed that the male adolescents had statistically stronger intention of participating rowing activity with higher satisfaction level of the activity in "overall satisfactory level of the activity." ( $\mathrm{t}=5.656, \mathrm{df}=611, \mathrm{p}<.001)$ and higher level of agreements in "the activity was interesting." ( $\mathrm{t}=$ 5.333, df $=637, \mathrm{p}<.001)$, "the activity was challenging." ( $\mathrm{t}$ $=4.556, \mathrm{df}=636, \mathrm{p}<.001)$, "my knowledge in rowing was enhanced." ( $\mathrm{t}=4.810$, df $=634, \mathrm{p}<.001)$, "my interest in rowing was enhanced." $(\mathrm{t}=7.362$, df $=636$, $\mathrm{p}<.001)$.

Table 5. Relationship of the Effectiveness of YRDP and their Intention.

\begin{tabular}{|l|c|c|c|c|c|c|}
\hline \multicolumn{1}{|c|}{ Intention } & \multicolumn{3}{|c|}{ YES (n=335) } & \multicolumn{3}{c|}{ NO (n=845) } \\
\hline \# Level of agreement for YRDP & $\begin{array}{c}\text { All } \\
\text { Mean (SD) }\end{array}$ & $\begin{array}{c}\text { Female } \\
\text { Mean (SD) }\end{array}$ & $\begin{array}{c}\text { Male } \\
\text { Mean (SD) }\end{array}$ & $\begin{array}{c}\text { All } \\
\text { Mean (SD) }\end{array}$ & $\begin{array}{c}\text { Female } \\
\text { Mean (SD) }\end{array}$ & $\begin{array}{c}\text { Male } \\
\text { Mean (SD) }\end{array}$ \\
\hline The activity was interesting. & $4.28(0.88)^{*}$ & $4.32(0.85)^{*}$ & $4.26(0.89)^{*}$ & $3.78(0.92)$ & $3.73(0.86)$ & $3.83(0.97)$ \\
The activity was challenging. & $4.34(0.85)^{*}$ & $4.34(0.87)^{*}$ & $4.33(0.85)^{*}$ & $3.94(0.93)$ & $3.90(0.87)$ & $3.96(0.98)$ \\
My knowledge in rowing was enhanced. & $4.19(0.86)^{*}$ & $4.18(0.84)^{*}$ & $4.20(0.88)^{*}$ & $3.78(0.93)$ & $3.74(0.89)$ & $3.81(0.96)$ \\
My interest in rowing was enhanced. & $4.28(0.81)^{*}$ & $4.31(0.85)^{*}$ & $4.26(0.79)^{*}$ & $3.61(0.97)$ & $3.55(0.92)$ & $3.66(1.01)$ \\
Overall satisfactory level of the activity. & $4.39(0.70)^{*}$ & $4.45(0.56)^{*}$ & $4.36(0.77)^{*}$ & $3.95(0.77)$ & $3.94(0.72)$ & $3.96(0.81)$ \\
\hline
\end{tabular}

$* \mathrm{P}<.001$

$\# 1$ = strongly disagree/dissatisfied; 5 = strongly agree/satisfied

\section{Discussion}

The purpose of this study is to investigate the intention of adolescents to participate in rowing activity and the factors which might influence their decisions. The results of chi-square analysis showed that the desire to start rowing activity was stronger for the male adolescents, desire declined with age for both gender groups. Similar findings related to PA participation are reported by Canadian Fitness and Lifestyle Research Institute (2002) that girls are less active than boys at all ages. This gap is evident in younger school age children and widens during adolescence. This also supports the works by Sallis (2000) that PA declined with age in industrialized countries, with the steepest decline occurring between the ages of 13 and 18.

Gender differences in the stated reasons for their intention in participating rowing activity may reflect different views of male and female adolescents. In the present study, female adolescents emphasized on social benefits or enjoyment orientations like "to have fun" while male adolescents stressed on psychological enhancement or achievement orientations such as "like the challenge". Similar issues are identified in the qualitative study conducted by O'Dea (2003) in which the most important factors motivating the participation in PA among adolescents in Australia were fun and enjoyment of challenges. The finding is consistent with and extends the review of qualitative studies of the Allender, Cowburn and Foster (2006), in which fun, enjoyment and social support were reported as predictors of PA participation in adolescents. According to self-determination theory (Ryan \& Deci, 2000), intrinsic and extrinsic motivation appear to be an important determinant of the female and male adolescents participation in rowing respectively.

A concern might be raised is more female adolescents than male adolescents who are not current participating in PA expressed interest in starting a rowing activity. Rowing is a non-traditional sport in Hong Kong. This can be explained by the findings of Orme (1991) and Mulvihill, Rivers and Aggleton (2000) that many girls were disappointed to the traditional sports offered in PE which was lack of variety. Additional support comes from the findings of Flintoff and Scraton (2001) that the nontraditional activities provided the opportunity for fun and enjoyment without competition.

It is noteworthy that interest in participating rowing activity increased with the score of the 1-min maximal rowing ergometer test. This finding is consistent with the arguments developed by Klint and Weiss (1987) and Weiss, Ebbeck and Horn (1997) that adolescents who 
see themselves as physically successful in sport are motivated to continue participation for skill development and have future expectations for success in sport. Further investigation is required to identify reasons for the discrepancy of the most stated reasons between male and female who desire to participate in rowing activity.

Another important finding in this study indicates the most stated reason that "no intention in participating a rowing activity is lack of interest". This observation supports the expectancy-value model of achievement choice as expressed by Eccles and her co-workers (1983) that children's interpretations of their previous performance influence their goals, expectations and task specific beliefs. This result confirms with the findings by Alexandris, Tsorbatzoudis and Grouios (2002) that the dimension of "lack of interest" contributes significantly to the prediction of amotivation. This finding is contrary to many studies (Allison et al., 1999a,b; Culp, 1998; Frankish, Milligan \& Reid, 1998; O’Dea, 2003; Robbins, Pender \& Kazanis, 2003; Saxena, Borzekowski \& Rickert, 2002; Sleap \& Wormald, 2001; Taylor, Legrand \& Newton, 1999) where lack of time was reported as a major barrier to PA. It maybe not surprised to find out that, rowing is a water sport, poor swimming skill was the second most stated reason for not interested in participating rowing activity.

Some of the barriers were stated by a significantly higher percentage of female adolescents than the male counterparts such as "unlike to sun exposure" and "don't like outdoor event". This supports the views of Dwyer and his co-workers (2006) that the main concern for the female adolescents participating in PA was body-centered issues such as menstruation, stereotypes about femininity, and related to physical appearance. Similar issues were identified by Allender, Cowburn and Foster (2006) in which the role models for female adolescents are usually feminine such as thin, beautiful and white skin.

\section{Conclusions and Recommendations}

The present study identifies the reasons for desiring to start rowing activity. The study show that the female adolescents are enjoyment oriented, while the male adolescents are achievement orientated. Lack of interest is the most stated reason for their no interest to start a rowing activity.
Different leisure activities were stimulated by different desires (Barber, Sukhi \& White, 1999). Future research should compare these results with other sports. In addition, motivations for their intention and initial participation may differ from continued participation. Further research is required to increase our understanding of their relationship.

The findings in the present study enhance our understanding in the attractions of participating in rowing activity to the adolescents, and what kind of factors that might weaken their interest. It is important to reinforce their needs for their intention, on the other hand, address these barriers in order to increase participation. For example, adjusting the contents of the promotion programme or providing various programmes that might increase the interest of the participants.

\section{Limitations}

The selected sample in the present study represented a small population of adolescents in Hong Kong, the result cannot be assumed to have external validity for all adolescents in the world.

\section{Acknowledgements}

The author would like to thank Mr. Xu Jia Wei, Steven for his valuable comments on the manuscript. Deep Appreciation is extended to Mr. Chan Chung Lun, Jacky for his time and effort to collect data.

\section{References}

Alexandris, K., Tsorbatzoudis, C., \& Grouios, G. (2002). Perceived constraints on recreational sport participation: Investigating their relationship with intrinsic motivation, extrinsic motivation, and amotivation. Journal of Leisure Research, 34(3), 233252.

Allender, S., Cowburn, G., \& Foster, C. (2006). Understanding participation in sport and physical activity among children and adults: a review of qualitative studies. Health Education Research, 21(6), 826-35. 
Allison, K.R., Dwyer, J.J., \& Makin, S. (1999a). Perceived barriers to physical activity among high school students. Preventive Medicine, 28, 608-615.

Allison, K.R., Dwyer, J.J., \& Makin, S. (1999b). Selfefficacy and participation in vigorous physical activity by high school students. Health Education Behavior, 26(1), 12-24.

Barber, H., Sukhi, H., \& White, S.A. (1999). The influence of parent-coaches on participant motivation and competitive anxiety in youth sport participation. Journal of Sport Behavior, 22, 162-180.

Biddle, S.J.H., Gorely, T., \& Stensel, D.J. (2004). Healthenhancing physical activity and sedentary behaviour in children and adolescents. Journal of Sports Sciences, 22, 679-701.

Brustad, R.J. (1988). Affective outcomes in competitive youth sport: The influence on intrapersonal and socialization factors. Journal of Sport and Exercise Psychology, 10, 307-321.

Busby, G. (1997). Modelling Participation Motivation in Sport. In J. Kremer, K. Trew \& S. Ogle (Eds.) Young People's Involvement in Sport. London: Roultledge.

Canadian Fitness and Lifestyle Research Institute (2002). Physical Activity Monitor. Available at: http://www. cflri.ca/eng/statistics/surveys/documents/02pam_02.pdf. Accessed May 2010.

Centers for Disease Control and Prevention. (2008). Physical activity and the health of young people. Available at: http://www.cdc.gov/HealthyYouth/ physical activity/facts.htm. Accessed May 2010.

Culp, R.H. (1998). Adolescent girls and outdoor recreation: A case study examining constraints and effective programming. Journal of Leisure Research, 30, 356379.

Duda, J.L. (1985). Goals and achievement orientations of Anglo and Mexican-American adolescents in sport and the classroom. International Journal of Intercultural Relations, 9, 131-150.
Dwyer, J.J., Allison, K.R., Goldenberg, E.R., Fein, A.J., Yoshida, K.K., \& Boutilier, M.A. (2006). Adolescent girls' perceived barriers to participation in physical activity. Adolescence, Spring, 41(161), 75-89.

Dzewaltowski, D.A., Noble, J.M., \& Shaw, J.M. (1990). Physical activity participation: Social cognitive theory versus the theory of reasoned action and planned behaviour. Journal of Sport and Exercise Psychology, 12, 388-405.

Eccles, P.J., Adler, T.F., Futterman, R., Goff, S.B., Kaczala, C.M., Meece, J.L., \& Midgley, C. (1983). Expectancies, values, and academic behaviors. In J. T. Spence (Ed.), Achievement and Achievement Motives (pp. 75-146). San Francisco, CA: W. H. Freeman.

Etnier, J., Salazar, W., Landers, D., Petruzzello, S., Han, M. \& Nowell, P. (1997). The influence of physical fitness and exercise upon cognitive functioning: a meta-analysis. Journal of Sport Exercise Psychology, 19(3), 249-277.

Fawcett, L.M., Garton, A.F., \& Dandy, J. (2009). Role of motivation, self-efficacy and parent support in adolescent structured leisure activity participation. Australian Journal of Psychology, 61(3), 175-182.

Flintoff, A., \& Scraton, S. (2001). Stepping into active leisure? Young women's perceptions of active lifestyles and their experiences of school physical education. Sport, Education and Society, 6, 5-21.

Frankish, C.J., Milligan, C.D., \& Reid, C. (1998). A review of relationships between active living and determinants of health. Social Science and Medicine, 47, 287-301.

Gould, D., Feltz, D., \& Weiss, M. (1985). Motives for participation in competitive youth swimming. International Journal of Sport Psychology, 16, 126140.

Hong Kong Sports Development Board (2000). Sports Participation Survey 1999. Hong Kong. 
Klint, K.A., \& Weiss, M.R. (1987). Perceived competence and motives for participating in youth sports: A test of Harter's Competence Motivation Theory. Journal of Sport Psychology, 9, 55-65.

Kremer, J., Trew, K., \& Ogle, S. (Eds.) (1997). Young People's Involvement in Sport. London: Routledge.

Mulvihill, C., Rivers, K., \& Aggleton, P. (2000). Views of young people towards physical activity: determinants and barriers to involvement. Health Education, 100(5), 190-199.

O'Dea, J. (2003). Why do kids eat healthy food? Perceived benefits of and barriers to healthful eating and physical activity among children and adolescents. Journal of the American Dietetic Association, 103(4), 497-501.

Orme, J. (1991). Adolescent girls and exercise: too much of a struggle? Education and Health, 9, 76-80.

Riddle, P.K. (1980). Attitudes, beliefs, behavioural intentions, and behaviours of women and men toward regular jogging. Research Quarterly for Exercise and Sport, 51, 663-674.

Robbins, L.B., Pender, N.J., \& Kazanis, A.S. (2003). Barriers to physical activity perceived by adolescent girls. Journal of Midwifery and Women's Health, 48, 206-212.

Ryan, R.M., \& Deci, E.L. (2000). Self-determination theory and the facilitation of intrinsic motivation, social development, and well-being. American Psychologist, 55, 68-78.

Sallis, J.F. (2000). Age-related decline in physical activity: A synthesis of human and animal studies. Medicine and Science in Sports and Exercise, 32, 1598-1600.

Saxena, R., Borzekowski, D.L., \& Rickert, V.L. (2002). Physical activity levels among urban adolescent females. Journal of Pediatric and Adolescent Gynecology, 15, 279-284.
Shephard, R. (1997). Curricular physical activity and academic performance. Pediatric Exercise Science, 9, 113-126.

Sleap, M., \& Wormald, H. (2001). Perceptions of physical activity among young women aged 16 and 17 years. European Journal of Physical Education, 6, 26-37.

Strauss, R.S., Rodzilsky, D., Burack, G., \& Colin, M. (2001). Psychosocial correlates of physical activity in healthy children. Archives of Pediatrics \& Adolescent Medicine, 155, 897-902.

Symons, C., Cincelli, B., James, T., \& Groff, P. (1997). Bridging Student Health Risks and Academic Achievement through Comprehensive School Health Programs. Journal of School Health, 67, 220-227.

Taylor, T., Legrand, N., \& Newton, J. (1999). Myth and reality: Exploring teenage schoolgirl sport participation. Journal of the International Council for Health, Physical Education, Recreation, Sport, and Dance, 35, 32-36.

van Mechelen, W., Twisk, J.W., Post, G.B., Snel, J., \& Kemper, H.C. (2000). Physical activity of young people: the Amsterdam Longitudinal Growth and Health Study. Medicine \& Science in Sports \& Exercise, 32, 1610-1616.

Weiss, M.R., Ebbeck, V., \& Horn, T.S. (1997). Children's self-perceptions and sources of physical competence information: a cluster analysis. Journal of Sports and Exercise Psychology, 19, 52-70.

White, S.A., \& Duda, J.L. (1994). The relationship of gender, level of sport involvement, and participation motivation to task and ego orientation. International Journal of Sport Psychology, 25, 4-18.

\section{Correspondence}

Robert Siu Kuen NG, PhD

ST802, Physical Education Section,

The Hong Kong Polytechnic University,

Hong Kong.

Tel: (852) 27666787

Fax: (852) 23301404

E-mail: sarobert@polyu.edu.hk 